\title{
Application of Rice Root Endophytic Bacteria in Ciherang Variety Rice (Oryza sativa) Seeds
}

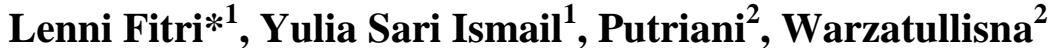 \\ ${ }^{1}$ Departement of Biology, Faculty of Mathematics and Natural Sciences, Universitas Syiah Kuala, Indonesia \\ ${ }^{2}$ Postgraduate Program, Faculty of Mathematics and Natural Sciences, Universitas Syiah Kuala, Indonesia \\ *Email: lennifitri@unsyiah.ac.id
}

Submitted: 31 October 2019. Revised: 11 January 2020. Accepted: 20 March 2020

\begin{abstract}
Endophytic bacteria are microorganisms that thrive in plant tissue without causing any negative effects to the host plants. The purpose of this study was to apply endophytic bacteria that have the potential to produce IAA hormones as biological agents in rice seeds. This research was conducted by testing IAA hormone using a spectrophotometer, testing HCN production using filter paper, biochemically identification of the isolate, and applicating endophytic bacteria into rice seeds. Endophytic bacteria have different abilities in producing IAA hormone. Based on the results of the study, the highest IAA concentration (57 ppm) was obtained from KSB1 (Potassium Solubilizing Bacteria) isolates and followed by KSB3 isolate with $56 \mathrm{ppm}$. All the endophytic bacteria isolates were unable to produce HCN. Results of the study showed that KSB1 and KSB3 isolate were able to influence the growth of root length by $5.62 \mathrm{~cm}$ and 6.70 respectively as well as the canopy height by $8.56 \mathrm{~cm}$ and $8.30 \mathrm{~cm}$ respectively. Based on observations of colony morphology, cell morphology and biochemical tests, KSB1 was presumably belong to the genus Staphylococcus. In this study, new information about endophytic bacteria that can increase the growth of Ciherang variety rice can be obtained. This study provides information that the application of environmentally friendly bacteria is important to preserve the environment and agriculture sustainability in Indonesia without reducing the productivity of rice.
\end{abstract}

Keywords: Oryza sativa L., endophytic bacteria; IAA hormone; plant growth promoting bacteria

How to Cite: Fitri, L., Ismail, Y. S., Putriani, \& Warzatullisna. (2020). Application of Rice Root Endophytic Bacteria in Ciherang Variety Rice (Oryza sativa. L) Seeds. Biosaintifika: Journal of Biology \& Biology Education, 12 (1), 21-27

DOI: http://dx.doi.org/10.15294/biosaintifika.v12i1.21697

\section{INTRODUCTION}

Rice is a very widely cultivated food crop in the world. The average of rice production in the world was 645 million tons in 2007. Rice belongs to the genus Oryza which includes approximately 25 species, spread in tropics and sub-tropics area. Rice requires relatively high nutrient intake and fertile land in order to grow and develop optimally (Gusmaini \& Kartikawati, 2015).

The presence of pathogenic microbes that cause disease is one of the factors that decrease the rice production. The efforts to prevent pathogenic microbes is by using chemical fertilizers. The use of chemical fertilizers is known to have an adverse effect in disrupting ecosystem balance and decreasing the amount of microbes present in the soil. Another effort that could be done to overcome this problem is by the application of endophytic bacteria to replace the use of chemical fertilizers (Momota et al. 2012).

Microbial diversity in Indonesia is very high, where one of the diversity is from the group of endophytic bacteria. This group of bacteria can be used as a biological fertilizer. Endophytic bacteria are thought to be able to increase plant defense systems against plant diseases because of its ability to produce antimi- crobial compounds, enzymes, salicylic acid, ethylene and other secondary compounds that play a role in inducing plant resistance (Backman \& Sikora 2008).

Endophytic bacteria, besides having a role in inducing plant growth by producing growth regulating compounds such as IAA hormone, also have a role as biocontrol agents. The role of endophytic bacteria as biocontrol agent is needed by plants in dealing with plant pests. The existence of these two roles is one of the factors that can determine the success of crop cultivation (Gusmaini et al. 2013). Distribution of endophytic bacteria into the plant is expected to produce efficiency in the use of fertilizers in nurseries as well as to increase plant resistance against pathogens. The purpose of this study was to apply endophytic bacteria that have a potency to produce IAA hormones in rice seeds (Ciherang variety) as biological agents.

The application of endophytic bacteria with an ecological approach which environmentally friendly is essential to preserve environment and agriculture sustainability in Indonesia without reducing its productivity. 


\section{METHODS}

\section{Plant Material}

This research was conducted at Microbiology Laboratory, Faculty of Mathematics and Natural Sciences, Universitas Syiah Kuala. Rice seeds (Ciherang variety) used in this study was obtained from the Aceh Besar rice field area. Rice seeds were soaked for 48 hours with endophytic bacterial isolates. The research design used was a Completely Randomized Design (CRD) with seven treatments and two replications. The treatments received were the KSB1 (Potassium Solubilizing Bacteria), KSB2, KSB3, KSB5, KSB6, KSB7 isolates and the aquadest as controls.

\section{Isolation of Endophytic Bacteria from Rice Roots (Ciherang Variety)}

Endophytic bacteria used in this study were taken from previous studies. These endophytic bacteria were isolated from rice roots (Ciherang variety) obtained from Aceh Besar rice fields (Warzatullisna et al. 2019).

\section{Preparation of Solution for IAA Standard Curve}

A total of $3 \mathrm{mg}$ tryptophan was dissolved in $50 \mathrm{ml}$ methanol. Each IAA solution (10 ppm, 20 ppm, 30 ppm, and $40 \mathrm{ppm}$ ) was inserted into test tube. Then methanol was added until the volume in each test tube reached $1000 \mu \mathrm{l}$. The solution was then homogenized and incubated for 60 minutes at room temperature. The absorbance of solutions were measured using spectrophotometer at a wavelength of $535 \mathrm{~nm}$.

\section{The Ability of Bacteria in Producing IAA}

Experiments for IAA hormone analysis were carried out quantitatively which the isolates grown in Trypticase Soy Broth (TSB) media were added with 1 g tryptophan then incubated at room temperature for 24 hours. The culture was then centrifuged at a speed of $3000 \mathrm{rpm}$ for 20 minutes. A total of $1 \mathrm{ml}$ supernatant obtained was added with $4 \mathrm{ml}$ Salkowski reagent $\left(150 \mathrm{ml} \mathrm{H} \mathrm{H}_{2} \mathrm{SO}_{4}+1.351 \mathrm{~g}\right.$ of $0.5 \mathrm{M} \mathrm{FeCl}_{3} \cdot 6 \mathrm{H}_{2} \mathrm{O}$ in 100 $\mathrm{ml}$ distilled water) and was put into a test tube. The mixture was then incubated in a dark place for 30 minutes and the change of color was observed. The change of color from yellow to reddish after incubation indicated that the isolate was able to produce IAA (Ketut et al., 2015). IAA concentration produced by the isolate was measured using spectrophotometer at a wavelength of $535 \mathrm{~nm}$. IAA solution standard curve was made using spectrophotometric results that showed the relation between the concentration of IAA solution standard $(\mathrm{x})$ and its absorbance $(\mathrm{y})$.

\section{The Ability of Bacteria to Produce HCN}

The 24-hour-old rice root endophytic bacteria were inoculated in solid glycine-supplemented medium. A filter paper was cut into petri dish size and soaked in picric acid solution for 1 minute. The filter paper was then placed on the lid of petri dish and incubated at room temperature for 4 days (Godinho, 2010).

\section{Biochemical Test of KSB1 Isolate}

Bacteria physiological characterization includes catalase, Triple Sugar Iron Agar (TSIA), Sulfide Indole Motility (SIM), Oxidative/Fermentative (O/F), and Methyl Red (MR)/Voges Proskauer (VP) test.

Catalase test was carried out by dropping $3 \% \mathrm{H}_{2} \mathrm{O}_{2}$ onto a slide as much as one drop. A bacteria colony was then taken using a sterile inoculating loop and mixed with $3 \% \mathrm{H}_{2} \mathrm{O}_{2}$.

TSIA test was carried out by isolating bacteria using sterile inoculating loop which were then inoculated in TSIA media. The needle containing pure culture was stabbed perpendicularly to the butt and dragged in zigzag pattern up to the surface of slant portion. The medium was then incubated at $37^{\circ} \mathrm{C}$ for 24 hours.

SIM test was conducted by isolating bacteria using sterile inoculating loop then inserted into the SIM medium in the test tube and incubated for 24 hours at $37^{\circ} \mathrm{C} . \mathrm{O} / \mathrm{F}$ test was carried out by inoculating bacteria to the medium then incubated at $37^{\circ} \mathrm{C}$ for 24 hours.

MR/VP test was perfomed by inoculating bacteria onto MR-VP medium using sterile inoculating loop then incubated for 24 hours at $37^{\circ} \mathrm{C}$. MR (Methyl Red) test media were added with 3-4 drops of methyl red reagent as an indicator to determine the ability of bacteria to oxidize glucose. VP (Voges Proskauer) media were added with 3 drops of $3 \% \mathrm{KOH}$ and 5 drops alpha naphthol.

\section{Potency of Endophytic Bacteria to Increase Rice Seed Growth}

The endophytic bacteria obtained were grown in TSB medium for 24 hours, then rice seeds (Ciherang variety) were immersed in suspension of endophytic bacteria for 24 hours. Rice seed used as a control was immersed in sterile distilled water without endophytic bacteria. A total of 10 rice seeds that have been soaked then were planted in a polybag with two replications. Germination was observed on the second day and growth parameters were observed after 7 days of incubation. Parameters observed were the number of seeds that germinated, the canopy height and the root length. 


\section{Data Analysis}

The data obtained from the experiment using Completely Randomized Design (CRD) with seven treatments and two replications then were analyzed using the 5\% Duncan test. Numbers followed by the same letters in the table show no significant difference in Duncan 5\% test.

\section{RESULTS AND DISCUSSION}

\section{Isolation and Characteristics of Endophytic Bacte- ria from the Roots of Rice Plants}

Based on the results of previous studies, a total of 7 endophytic bacterial isolates were obtained from rice roots. Morphological characterization of colonies and cells of isolates obtained was conducted as initial characterization. The shape and color of colonies obtained were varied. Generally, a single colony from purification of endophytic bacteria had white color, circular form with smooth margin, and raised elevation (Warzatullisna et al. 2019).

The morphological characterization of colonies and cells of endophytic bacteria isolated from the roots of rice plants can be seen in Figure 1 and Table
The colors of bacterial colonies were varied due to the presence of pigments produced by bacteria. Some external factors that could provide changes in their original color are medium, $\mathrm{pH}$ and temperature. Narsing et al (2017) stated that the color of bacterial colonies was caused by the presence of pigments such as carotenoids, melanin, violacein, prodigiosin, pyocyanin, actinorhodin, and zeaxanthin. Morphological characteristics of endophytic bacteria from seven isolates of rice root endophytic bacteria could be seen at Table 1.

Based on the results of Gram staining test, three isolates (KSB1, KSB5 and KSB6) belonged to Gram positive bacteria, while four isolates (KSB2, KSB3 and KSB7) belonged to Gram negative bacteria. Sunatmo (2010) stated that Gram positive bacteria has a greater number of peptidoglycan in cell walls compared to Gram negative bacteria, about $40-80 \%$ of peptidoglycan from the dry weight of the cell wall. The thickness of the cell wall is around $30-80 \mathrm{~nm}$. In general, the cell wall of Gram negative bacteria is thinner than Gram positive bacteria. Gram negative bacteria contain a higher percentage of lipids than Gram positive bacteria. 1.

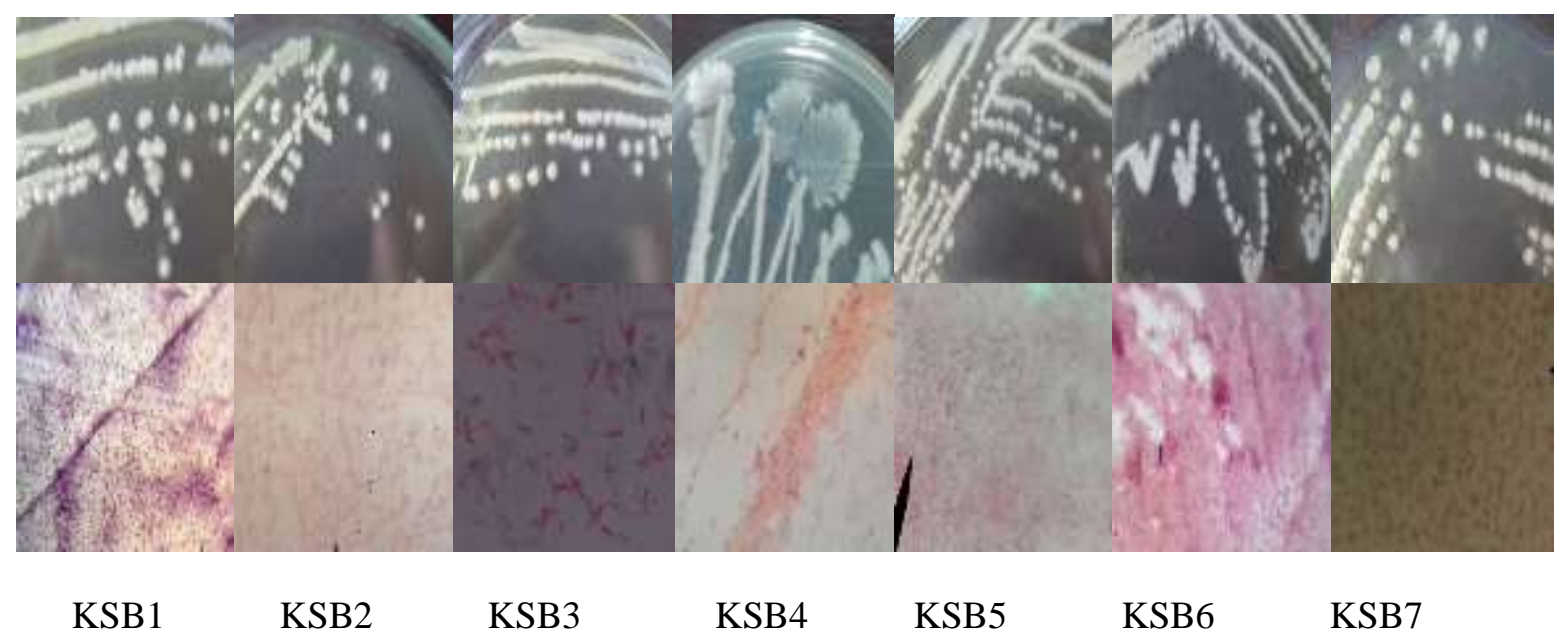

Figure 1. Morphology of 24 hour old rice roots endophytic bacteria colonies on NA media (top row); and cell morphologies of the isolates after Gram staining test (100x magnification, bottom row)

Table 1. Morphological characteristics of endophytic bacterial isolates

\begin{tabular}{lcccc}
\hline \multirow{2}{*}{ Isolate } & \multicolumn{4}{c}{ Morphological characteristics } \\
\cline { 2 - 5 } & Form & Margin & Elevation & Color \\
\hline KSB1 & Circular & Entire & Convex & Milky White \\
KSB2 & Circular & Entire & Convex & Milky White \\
KSB3 & Circular & Entire & Raised & Milky White \\
KSB4 & Filamentous & Filiform & Raised & Milky White \\
KSB5 & Circular & Entire & Raised & Milky White \\
KSB6 & Circular & Entire & Raised & Milky White \\
KSB7 & Concentric & Undulate & Raised & Cream Colored \\
\hline
\end{tabular}

KSB: Potassium Solubilizing Bacteria 


\section{IAA Production}

Observations on IAA production showed that all bacteria were able to produce IAA with various concentrations. IAA measurement results showed that concentrations obtained from KSB1, KSB2, KSB 3, KSB5, KSB 6, and KSB 7 was 57, 40, 56, 53, 38, and $55 \mathrm{ppm}$ respectively (Figure 2). In this study, hormone concentrations produced by endophytic bacterial isolates are not significantly different. However, based on the observations, the concentration of the IAA hormone that KSB1 produced (57 ppm) was slightly higher than the other isolates. According to a study by Pambudi et al. (2017), the highest IAA con- centration was found in TGR 2.17 bacteria from rice field soil which was $0.116 \mathrm{ppm}$. The results obtained from that study was very low. The low IAA produced could be caused by the non-optimal conditions during the experiment, probably due to the bacterial cultures used had been cultured for too long (120 hours).

Bose et al. (2013) stated that IAA produced by bacteria was influenced by the supernatant, incubation time and tryptophan concentration. Variation of IAA concentration produced by each isolate was estimated to occur due to the difference of endophytic bacteria ability in synthesizing tryptophan into IAA.

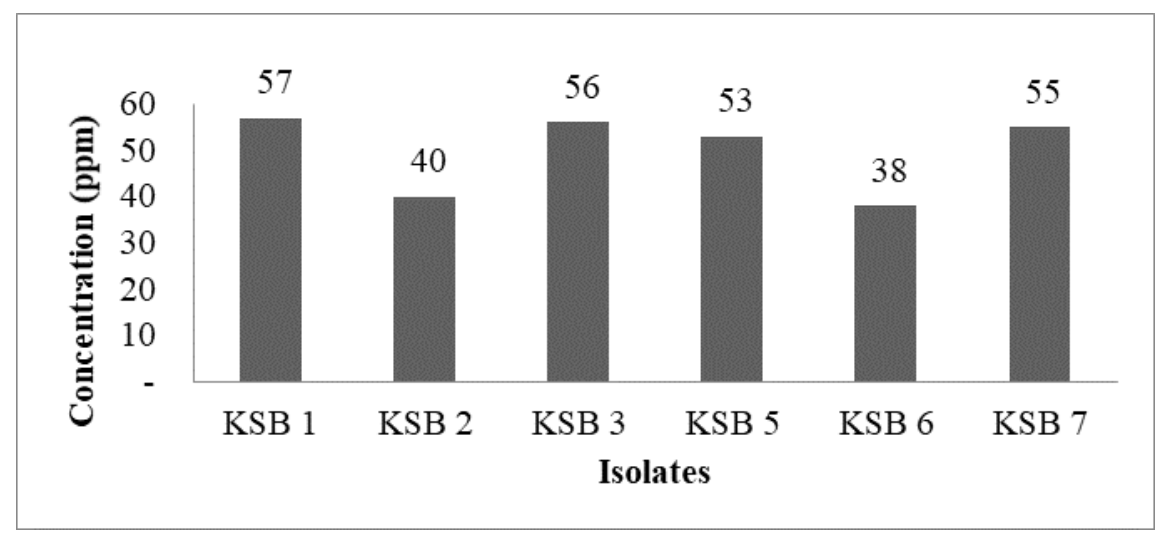

Figure 2. IAA concentration measurements of endophytic bacterial isolates

Endophytic bacteria that was able to produce IAA was characterized by pink discoloration in the media. The darker the color of media indicated the higher hormones produced by endophytic bacteria. According to Dewi et al. (2016), bacteria which was able to produce IAA would turn the media into pink color because IAA bound to Fe and formed a complex compounds.

\section{The Ability of Bacterial Isolates to Produce Hy- drogen Cyanide (HCN)}

The results showed that all endophytic bacteria from rice roots were unable to produce $\mathrm{HCN}$. It could be seen by the unchanging color of filter paper (Figure 3). Agustiansyah et al. (2013) stated that out of four isolates isolated from Gogo rice, only one isolate that was able to produce HCN. Yellow filter paper indicated that the isolate did not produce $\mathrm{HCN}$, meanwhile light brown, dark brown and brick red colors indicated $\mathrm{HCN}$ production. $\mathrm{HCN}$ works by inhibiting the activity of enzymes that have metal ion cofactor such as $\mathrm{Cu}^{2+}$, for example the cofactor in cytochrome C oxidase (Martínez et al. 2010).

According to Agustiansyah et al. (2013), HCN is secondary metabolites produced by Pseudomonas spp. that showed antimicrobial activity. The reaction between picric acid in filter paper and hydrogen cyanide produced by bacteria would form sodium cyanide, resulting in color changes in filter paper. Sodium cyanide is formed through absorption of cyanide gas by picric acid through the reaction between sodium and ammonia. The benefits of this test was to detect the presence of cyanide. The formation of cyanide was influenced by the presence of oxygen and the addition of glycine in the medium.

$\mathrm{HCN}$ acts as biocontrol by inhibiting the growth of pathogenic organisms. Hydrogen cyanide $(\mathrm{HCN})$ is a deadly poison that works by inhibiting the system between cell spaces, so that oxygen cannot circulate in cell tissues. The dangers of cyanide acid to health especially occurs in respiratory system. It is because oxygen in the blood will be bounded by HCN and cellular respiration cannot occur. The lack of oxygen in cells will cause death if it did not get immediate help. HCN content of $50 \mathrm{mg} / \mathrm{kg}$ in food is still safe for human consumption, but consumption levels that exceed $50 \mathrm{mg} / \mathrm{kg}$ could cause poisoning (Agbodjato et al. 2015). 


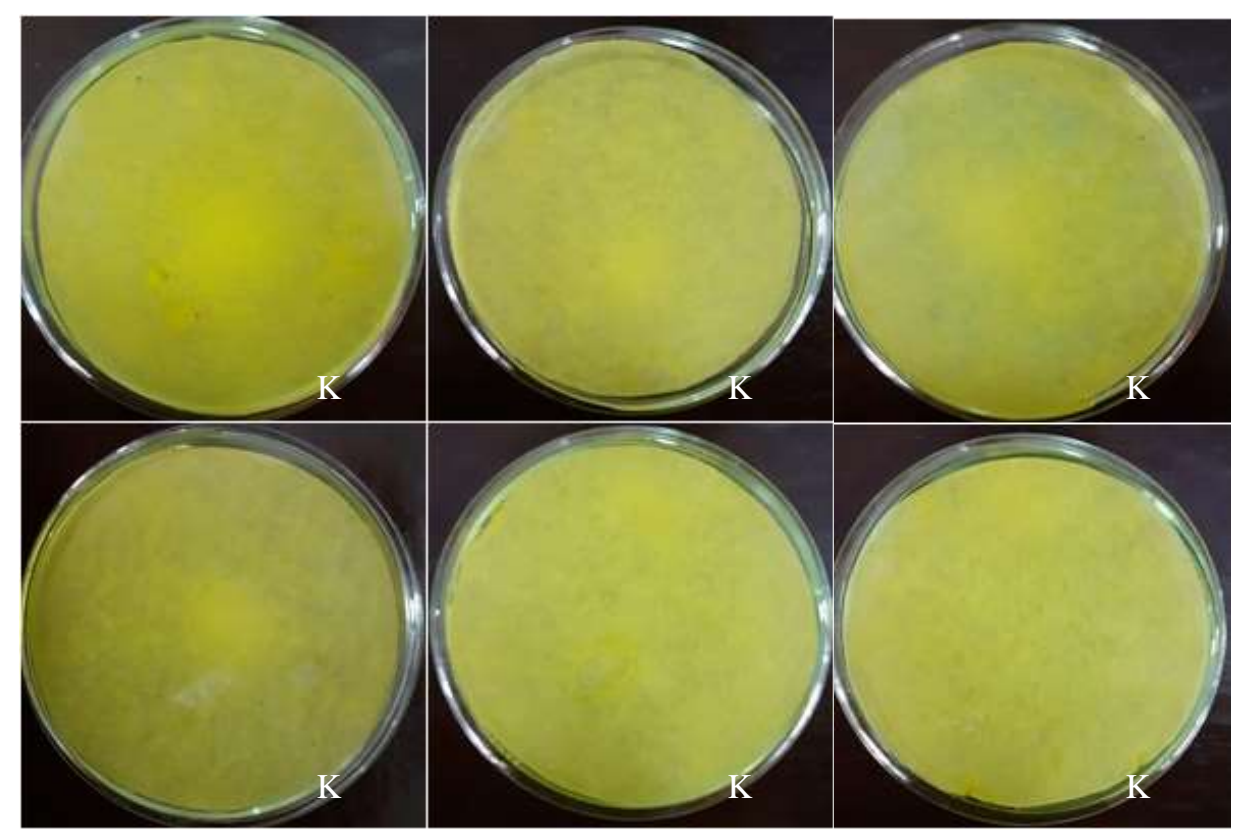

Figure 3. Endophytic bacterial isolates ability test in producing Hydrogen Cyanide (HCN)

\section{Identification of KSB1}

Biochemical identification of rice root endophytic bacteria was only conducted to isolate that produce the highest IAA hormone. The results of biochemical identification showed that KSB1 was positive for the catalase test, it means that KSB1 had catalase enzymes that play a role in breaking $\mathrm{H}_{2} \mathrm{O}_{2}$ into $\mathrm{H}_{2} \mathrm{O}$ and $\mathrm{O}_{2}$. A positive reaction was also shown by TSIA test with yellow changes in the butt and slant portions of media. This showed that these bacteria ferment glucose, lactose and sucrose. The $\mathrm{O} / \mathrm{F}$ test showed positive results by the changing of the media colour. This test was performed to determine the ability of bacteria to carry out respiration (oxidative) and carbohydrate fermentation (glucose). Meanwhile, the SIM and MR/VP test showed negative results. Identification of bacterial isolate was based on observations of colony morphology, cell morphology and biochemical tests by referring to the book of Cowan and Steel's Manual for the Identification of Medical Bacteria (Barrow et al. 2003).

The results showed that KSB1 was presumably belong to the genus Staphylococcus. Staphylococcus are Gram positive cocci about $0.5-1.0 \mu \mathrm{m}$ in diameter. Staphylococcus grow in form of clusters, pairs or in short chains arrangements. The configuration of the bacteria helps to distinguish Micrococcus and Staphylococcus from Streptococcus, which usually grow in chains. However, observations must be made on cultures grown in broth medium, because Streptococcus grown on solid medium may appear as clumps. Several fields should be examined before deciding whether clumps or chains are present (Baron, 1996).

\section{Endophytic Bacterial Ability in Increasing Rice Growth}

Based on the results of the application that has been done, the rice plants treated with endophytic bacteria showed a good growth response. In general, all treatments with endophytic bacteria can increase rice growth compared to the control. However, some endophytic bacteria isolates such as KSB1, KSB3, KSB5 and KSB7 are able to increase the growth rate of rice plants significantly. Rice plant growth rate was based on Duncan's analysis $(\alpha=5 \%)$ (Table 2). This result showed that endophytic bacteria affect the growth of the seeds and the ability to stimulate growth was different, depended on the bacteria. Based on all parameters observed, not all treatments showed an increase in growth. This showed that not all endophytic bacteria isolated from plants had the potency to increase plant growth.

The ability of endophytic bacteria to spur rice's growth was seen after 7 days observation. Based on the root length and canopy height parameters, it could be seen that several treatments of endophytic bacteria application were significantly showed different results compared to controls. This showed that applicating endophytic bacteria into seeds significantly affected rice growth. Based on the observations, the growth of rice plants applied by all isolates was not significantly different according to Duncan's test results. However, the highest growth rate of rice plants indicated by root length and canopy height was shown by isolates of KSB3 and KSB1. Based on the results, KSB3 had root length of $6.70 \mathrm{~cm}$ and canopy height of $8.30 \mathrm{~cm}$, followed by KSB1 with root length of $5.62 \mathrm{~cm}$ and crown height of $8.56 \mathrm{~cm}$. In the previous study by Warzatullisna et al. (2019), KSB3 was the isolate that 
was able to produce the highest potassium. It is suspected that potassium was the macronutrient that played an important role in plant growth and production. In addition, KSB3 was also able to produce high IAA with high concentration (56 ppm).

Table 2. The results of endophytic bacteria application in rice plants

\begin{tabular}{|c|c|c|}
\hline Treatment & Root Lenght $(\mathrm{cm})$ & Canopy Height $(\mathrm{cm})$ \\
\hline Control & $3.65 \mathrm{a}$ & $4.84 \mathrm{a}$ \\
\hline $\begin{array}{l}\text { KSB1 } \\
\text { isolate }\end{array}$ & $5.62 \mathrm{ab}$ & $8.56 \mathrm{c}$ \\
\hline $\begin{array}{l}\text { KSB2 } \\
\text { isolate }\end{array}$ & $5.26 \mathrm{ab}$ & $7.24 \mathrm{abc}$ \\
\hline $\begin{array}{l}\text { KSB3 } \\
\text { isolate }\end{array}$ & $6.70 \mathrm{~b}$ & $8.30 \mathrm{bc}$ \\
\hline $\begin{array}{l}\text { KSB5 } \\
\text { isolate }\end{array}$ & $6.62 \mathrm{ab}$ & $7.02 \mathrm{abc}$ \\
\hline $\begin{array}{l}\text { KSB6 } \\
\text { isolate }\end{array}$ & $4.49 \mathrm{ab}$ & $6.17 \mathrm{abc}$ \\
\hline $\begin{array}{l}\text { KSB7 } \\
\text { isolate }\end{array}$ & $6.21 \mathrm{ab}$ & $5.91 \mathrm{abc}$ \\
\hline
\end{tabular}

A study by Abdul et al. (2012) showed that endophytic bacteria from rice roots could increase the growth of Gogo rice seeds with a root length of 6.31 $\mathrm{cm}$ and a height of $7.24 \mathrm{~cm}$. That condition occurred because the isolate was able to produce the highest IAA. The presence of IAA produced by bacteria is one of the factors that makes endophytic bacteria could increase the plant growth. The utilization of endophytic bacteria as a potential pathogen suppressor had been widely reported. In addition, endophytic bacteria are also able to produce secondary metabolites, dissolve potassium and produce IAA to increase plant growth from pathogenic attack.

In this study, new information about endophytic bacteria that can increase the growth of Ciherang variety rice can be obtained. This study provide information about the application of environmentally friendly bacteria that is important to preserve the environment and agriculture sustainability in Indonesia without reducing the productivity of rice.

\section{CONCLUSION}

Based on the results, it was found that all endophytic bacteria isolates produced the IAA hormone and KSB1 produced slightly higher hormone concentration by $57 \mathrm{ppm}$. Based on HCN test, all endophytic bacteria were unable to produce $\mathrm{HCN}$, it was indicated by the absence of discoloration in glycinesupplemented medium. Based on the results of the application of endophytic bacteria in rice plants, all endophytic bacteria were able to accelerate the growth of rice plants. However, the isolates that gave the highest growth rate was KSB3 isolate with a rice root length of $6.70 \mathrm{~cm}$ and a canopy height of 8.30 $\mathrm{cm}$, followed by KSB1 with root length and canopy height were 5.62 and $8.56 \mathrm{~cm}$ respectively. The results of biochemical tests showed that KSB1 was presumably belong to the genus Staphylococcus.

\section{ACKNOWLEDGEMENTS}

The author are thankful for the support of RISTEKDIKTI for providing Master Thesis Research Grant in 2019.

\section{REFERENCES}

Abdul, M., Wiyono, S. \& Suwarno. (2012). Isolation of Endophytic Bacteria from Upland Rice and Its Role as Biocontrol Agents and Plant Growth Inducer. Jurnal Fitopatologi, 8(3), 57-64.

Agbodjato, N.A., Noumavo, P.A., Baba-Moussa F., Salami, H.A., Sina, H., Sèzan, A., Bankolé, H., Adjanohoun, A., \& Baba-Moussa, L. (2015). Characterization of potential plant growthpromoting rhizobacteria isolated from maize (Zea mays L.) in Central and Northern Benin (West Africa). Journal Applied and Environmental Soil Science, 2015, 1-9.

Agustiansyah, Ilyas, S., Sudarsono, \& Machmud, M. (2013). Karakteristik Rizobakteri yang Berpotensi Mengendalikan Bakteri Xanthomonas oryzae Pv.Oryzae dan Meningkatkan Pertumbuhan Tanaman Padi. Jurnal Hama Penyakit Tumbuhan, 13(1), 42-51.

Backman, P.A \& Sikora, R.A. (2008). Endophytes: an emerging tool for biological control. Journal Bio Control, 46 (1), 1-3.

Barrow, G.I. \& Filtham, R.K.A. (2003). Cowan and Steel's Manual For Identification of Medical Bacteria. USA: Cambridge University Press.

Baron, S. (1996). Medical Microbiology, 4th edition. Universitas of Texas Medical Branch at Galveston.

Bose, A., Shah, D. \& Keharia, H. (2013).Production of indole-3-aceticacid (IAA) by the white Rot fungus Pleurotus Ostreatus under Submerged Condition of Jatropha Seedcake. Journal Mycolog,. 4(2),103-111.

Dewi, T.K., Suryanggono, J., \& Agustiyanti, D. (2016). Isolasi dan Uji Aktivitas Bakteri Penghasil Hormon Tumbuh IAA (Indole-3-Acetic Acid) dan Bakteri Perombak Protein dari Tanah Pertanian Tual, Maluku Tenggara. Prosiding Seminar Nasional Masyarakat Biodiversitas Indonesia. (pp.271-276). 
Gusmaini, Aziz, S.A., Munif, A., Sopandie, D., \& Bermawie, N. (2013). Potency of Endophytic Bacteria to Increase the Growth, Biomass, and Andrographolide Yields of the Bitter King. Journal Littri, 19(4), 167-177.

Gusmaini \& Kartikawati, A. (2015) Isolasi dan Karakterisasi Bakteri Endofit Berasal dari Tanaman Lada Bangka. Prosiding Seminar Teknologi Cengkeh, Lada dan Pala. 3 (pp.159-168).

Godinho, A., Ramesh, R., \& Bhosle, S. (2010). Studi Mengenai Bakteri Sand Dune Sebagai Pemacu Pertumbuhan Pada Tanaman Terong. Journal of Agricultural Science, 6, 555-564.

Ketut, D.T.S., Suharjono, \& Sarjiya, A. (2015). Uji Potensi Bakteri Penghasil Hormon IAA (Indole Acetic Acid) dari Tanah Rhizosfer Cengkeh (Syzigium aromaticum L.). Jurnal Biotropika, 3(2), 9194.

Martínez-Viveros, O., Jorquera, M.A., Crowley, D.E., Gajardo, G., \& Mora, M.L. (2010). Mechanisms and practical considerations involved in plant growth promotion by rhizobacteria. Journal of Soil Science and Plant Nutrition, 10(3), 293-319.

Momota, P., Singh, B.K., \& Devi, S.I. (2012). Role of Endophytic Microorganism in Sustainable Agriculture. Journal Biology, 3, 69-77.
Munif, A., Wiyono, S., \& Suwarno. (2012). Pemanfaatan Bakteri Endofit untuk Meningkatkan Pertumbuhan dan Kesehatan Tanaman Padi Gogo. Prosiding Seminar Hasil-hasil Penelitian IPB. (pp 349-417).

Pambudi, A., Susanti, \& Priambodo, T.W. (2017). Isolasi dan Karakterisasi Bakteri Tanah Sawah di Desa Sukawali dan Desa Belimbing, Kabupaten Tangerang. Jurnal Biologi, 10(2), 105-113.

Putriani, Fitri, L., \& Ismail, Y.S. (2019). The Potential Endophytic Bacteria Isolated from Rice (Oryza Sativa L.) as Biofertilizer. Biosaintifika: Journal of Biology \& Biology Education, 11(2), 171-178.

Rao N.M.P., Xiao, M., \& Li W-J. (2017). Fungal and Bacterial Pigments: Secondary Metabolites with Wide Applications. Frontier in Microbiology, 8,113.

Sunatmo, T.I. (2007). Eksperimen Mikrobiologi Dalam Laboratorium. Bogor: Penerbit Ardy Agency.

Warzatullisna, Fitri, L. \& Ismail, Y.S. (2019). Potential of Endophytic Bacteria from Rice Root (Oryza Sativa L.) as Potassium Solvent. Biodiversitas, 20, 1303-1308. 